Article

\title{
Quantify Coal Macrolithotypes of a Whole Coal Seam: A Method Combing Multiple Geophysical Logging and Principal Component Analysis
}

\author{
Chao Cui ${ }^{1,2,3}$, Suoliang Chang ${ }^{4, *}$, Yanbin Yao ${ }^{1,2,3, *(\mathbb{D})}$ and Lutong Cao $1,2,3,5$ \\ 1 School of Energy Resource, China University of Geosciences, Beijing 100083, China; \\ 2106180051@cugb.edu.cn (C.C.); ltcaocugbchina@163.com (L.C.) \\ 2 Coal Reservoir Laboratory of National Engineering Research Center of CBM Development \& Utilization, \\ China University of Geosciences, Beijing 100083, China \\ 3 Beijing Key Laboratory of Unconventional Natural Gas Geological Evaluation and Development Engineering, \\ Beijing 100083, China \\ 4 College of Mining Engineering, Taiyuan University of Technology, Taiyuan 030024, China \\ 5 CCTEG Coal Mining Research Institute, Beijing 100013, China \\ * Correspondence: sl.chang@sxsdwt.com.cn (S.C.); yyb@cugb.edu.cn (Y.Y.)
}

check for

updates

Citation: Cui, C.; Chang, S.; Yao, Y.; Cao, L. Quantify Coal

Macrolithotypes of a Whole Coal

Seam: A Method Combing Multiple Geophysical Logging and Principal Component Analysis. Energies 2021, 14, 213. https://doi.org/10.3390/ en14010213

Received: 14 November 2020 Accepted: 30 December 2020 Published: 3 January 2021

Publisher's Note: MDPI stays neutral with regard to jurisdictional clai$\mathrm{ms}$ in published maps and institutional affiliations.

Copyright: $(2021$ by the authors. Licensee MDPI, Basel, Switzerland. This article is an open access article distributed under the terms and conditions of the Creative Commons Attribution (CC BY) license (https:// creativecommons.org/licenses/by/ $4.0 /)$.

\begin{abstract}
Coal macrolithotypes control the reservoir heterogeneity, which plays a significant role in the exploration and development of coalbed methane. Traditional methods for coal macrolithotype evaluation often rely on core observation, but these techniques are non-economical and insufficient. The geophysical logging data are easily available for coalbed methane exploration; thus, it is necessary to find a relationship between core observation results and wireline logging data, and then to provide a new method to quantify coal macrolithotypes of a whole coal seam. In this study, we propose a L-Index model by combing the multiple geophysical logging data with principal component analysis, and we use the L-Index model to quantitatively evaluate the vertical and regional distributions of the macrolithotypes of No. 3 coal seam in Zhengzhuang field, southern Qinshui basin. Moreover, we also proposed a S-Index model to quantitatively evaluate the general brightness of a whole coal seam: the increase of the S-Index from 1 to 3.7, indicates decreasing brightness, i.e., from bright coal to dull coal. Finally, we discussed the relationship between S-Index and the hydro-fracturing effect. It was found that the coal seam with low S-Index values can easily form long extending fractures during hydraulic fracturing. Therefore, the lower S-Index values indicate much more favorable gas production potential in the Zhengzhuang field. This study provides a new methodology to evaluate coal macrolithotypes by using geophysical logging data.
\end{abstract}

Keywords: coal macrolithotype; PCA methodology; coalbed methane; geophysical logging; Zhengzhuang field

\section{Introduction}

With the depletion of conventional energy sources, coalbed methane (CBM) is an alternative unconventional resource that has been studied by considerable scholars [1-4]. CBM extraction also makes a critical difference in improving mine safety and reducing greenhouse gas emissions [5,6]. Qinshui Basin in China is the most important CBM production area with in-place CBM resources of approximately $3.28 \times 10^{12} \mathrm{~m}^{3}$ [7]. However, Due to the low porosity, low permeability and the strong heterogeneity of $\mathrm{CBM}$ reservoir, quite a number of CBM wells are characterized by low gas productivity (commonly $<1000 \mathrm{~m}^{3} /$ day) and low exploitation efficiency [8]. Coal seam permeability as a key parameter for CBM production is largely determined by coal macrolithotypes which include bright coal, semibright coal, semi-dull coal, and dull coal [9-14]. Coal macrolithotypes drastically affect the key reservoir physical characteristics such as the fracture distribution, the rock mechanics properties, and the gas-containing property [15-18]. Therefore, investigating the 
coal macrolithotype distribution is important for reservoir characterization and hydrofracturing design.

Coal drilling and down-hole identification are the most direct methods to identify coal macrolithotypes $[6,19]$. However, intact core is difficult to obtain during the coal drilling, and the macrolithotype information can only be obtained from the underground coal working face $[16,20]$. Compared to these methods, geophysical logging has becoming an important way for CBM exploration because of its low cost and high efficiency for stratigraphic continuity evaluation [21,22]. Thus, to find a method to predict the vertical and regional distributions of coal macrolithotypes by using only the geophysical logging data, will bring key technique progress for exploration and exploitation of CBM.

In recent years, researchers have used various logging curves to evaluate the physical properties of coal reservoirs such as coal texture, gas content, permeability, mechanical properties, and coal petrologic parameters [1,6,19,23-30]. For coal macrolithotype, $\mathrm{Xu}$ et al. [20] investigated the coal macrolithotype characteristics based on analysis of the acoustic time difference (AC), density (DEN), natural gamma (GR), and deep lateral resistivity (LLD) logging curves. This method gives the referenced logging interval values for coal macrolithotypes identification; however, this method is inapplicable for some outliers that are outside the interval values. Based on a linear regression analysis, Tao et al. [16] adopted the DEN, AC and GR logging curves to identify coal macrolithotype, however this method is only applicable for certain reservoir types. Zhao et al. [31] introduced two logging curves (NGS (natural gamma-ray spectroscopy) and XMAC (cross-dipole array acoustic)) to qualitatively identify the coal macrolithotypes, but for field application, the data acquisition is difficult or uneconomical. In general, well applicability and low-cost are commonly two primary goals for identifying coal macrolithotype by logging data.

Principal component analysis (PCA) is a multivariate statistical method that uses the principle of dimensionality reduction to simplify multivariate data by converting multiple indicators into a few comprehensive indicators with the least loss of data and information [32-34]. The PCA method has been approved effective for quantitative identification of coal texture types [6,35], however, the application for quantifying coal macrolithotypes was not reported. In this study, a PCA is firstly proposed to identify the coal macrolithotypes by using 104 core samples from 29 wells. Secondly, the vertical and regional distributions of the macrolithotypes of the No. 3 coal seam are evaluated in the Zhengzhuang field in the southern Qinshui basin. Finally, this study discusses the influence of coal brightness of a single well on the development of the hydraulic fractures.

\section{Geological Background}

\subsection{Tectonics}

Qinshui basin located in the south-central region of North China is a Mesozoic basin evolved from the late Paleozoic, and it is a large north-to-east symmetrical syncline basin $[7,36]$. This basin is surrounded by the Wutai Mountains to the north, the Zhongtiao Mountains to the south, the Huo Mountains to the west, and the Taihang Mountains to the east [8]. Zhengzhuang field covering an area of $834.4 \mathrm{~km}^{2}$ is located in the south of Qinshui Basin. Since the occurrence of coal accumulation in the Carboniferous Permian, the Zhengzhuang CBM field has experienced the Indosinian orogenesis (late Permian-Triassic), Yanshan orogenesis (Jurassic-Early Cretaceous), early Himalayan orogenesis (Late Eocene) and late Himalayan orogenesis (Late Tertiary) successively [37]. During the Indosinian, the Zhengzhuang field was uplifted slightly due to the weak compressive tectonic stress along the N-S direction [38]. The basic shape of the northeastern syncline was formed under the NW-SE compressive stress because of the strong tectonic movement in Yanshan orogenesis. There was magmatic activity developed in the northern and southern regions of the basin, which further increased the degree of coal metamorphism [10]. In the early Himalayan period, the NW-SE principal compressive stress transformed to the NWW-SEE extensional stress [39]. When it came to the late Himalayan period, the 
regional principal compressive stress was transformed to the NNE-SSW, after which the strata experienced uplift and erosion [40].

In general, the Zheng Zhuang field is a plunging syncline with the Sitou fault in the southest and with open boundaries in the north and west. The strata have a gentle dip of $2-7^{\circ}$ with an average of $4^{\circ}$. In the study area, there are two major normal faults (Sitou and Houchengyao faults) and some minor normal faults in the NE-SW direction. The thrust faults are only locally developed in the northeast of the study area (Figure 1).

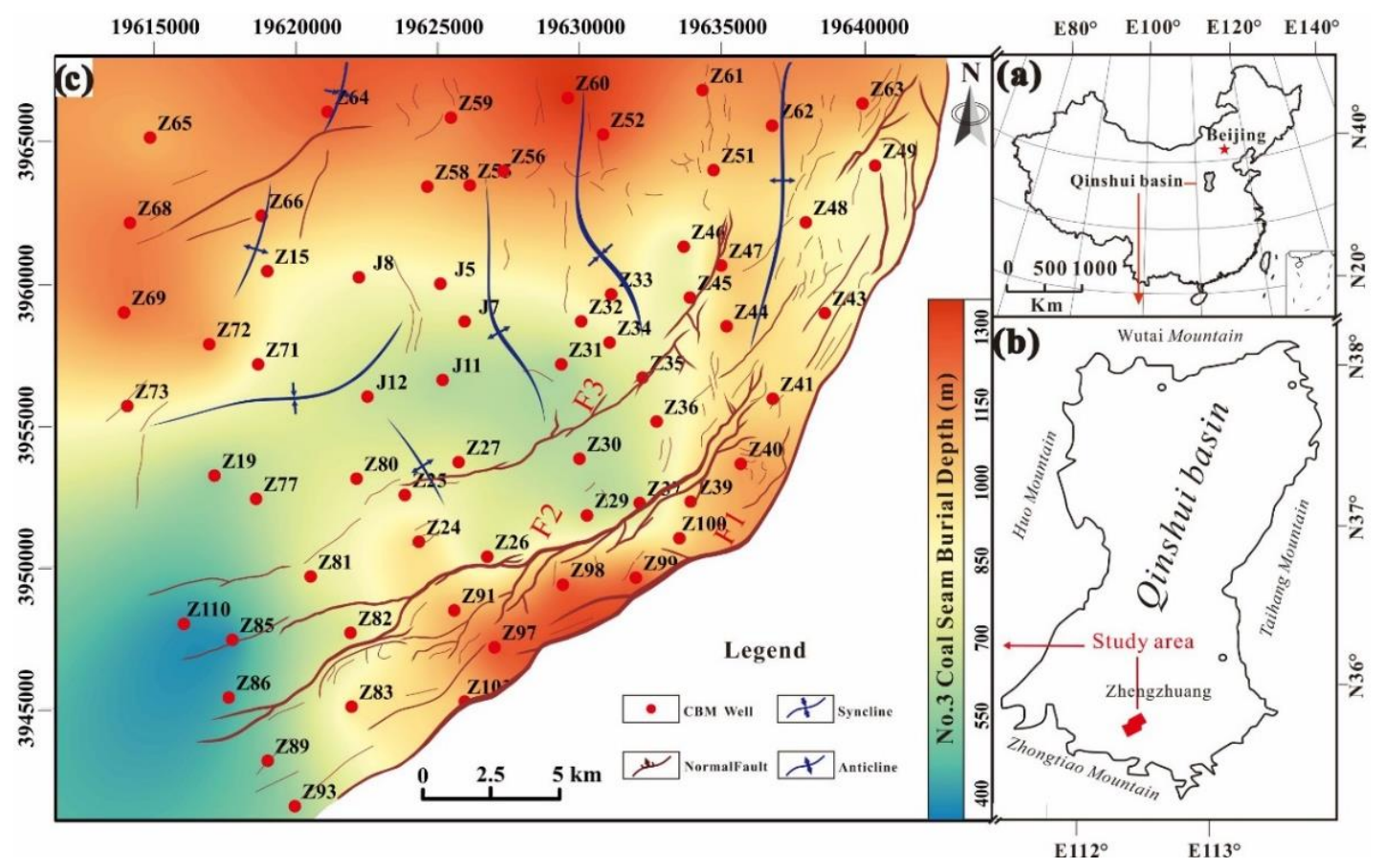

Figure 1. Map showing the location and geological structures of the Zhengzhuang field in the southern Qinshui Basin, North China. (a) Location of Qinshui Basin in China. (b) Location of the Zhengzhuang field in Qinshui Basin. (c) Structure of the Zhengzhuang field. F1 = Sitou fault; F2 = Houchengyao fault; F3 = Zhengzhong fault.

\subsection{Coal Measurements and Coal Seams}

The North China Craton Basin was eroded from the Silurian to Mississippian time, with the subsiding basin receiving sediment from Pennsylvanian to Triassic [7]. The basin developed Pennsylvanian Benxi Formation $\left(C_{2} b\right)$, Taiyuan Formation $\left(C_{3} t\right)$, Permian Shanxi Formation $\left(\mathrm{P}_{1}\right)$, Xiashihezi Formation $\left(\mathrm{P}_{1} \mathrm{x}\right)$, Shangshihezi Formation $\left(\mathrm{P}_{2} \mathrm{~s}\right)$, Shiqianfeng Formation $\left(\mathrm{P}_{2}\right.$ sh), and Triassic-Quaternary deposits [41]. The Taiyuan and Shanxi Formations are the main coal-bearing strata, with an average thickness of $150 \mathrm{~m}$. The main CBM reservoirs are the No. 3 coal seam of Shanxi Formation and the No. 15 coal seam of Taiyuan Formation, which have good lateral continuity with total thicknesses of 7-16 m [36].

The Shanxi Formation mainly contains sandstone, dark grey or grey-black mudstone and coal seams (Figure 2). The No. 3 coal seam of the lower Shanxi Formation, which is the focus of this study, has a relatively stable structure and is the main minable seam in Zhengzhuang field. The burial depth of the No. 3 coal seam is ranging from $261.7 \mathrm{~m}$ to $1045.6 \mathrm{~m}$ with an average of $882.1 \mathrm{~m}$. The thickness of the No. 3 coal is $2.3 \mathrm{~m}-7.73 \mathrm{~m}$ with an average of $6.11 \mathrm{~m}$. The No. 3 coal seam is within the anthracite coal rank and the gas content ranges from 10 to $37 \mathrm{~m}^{3} / \mathrm{t}$ [41,42]. The coal structures of the No. 3 coal seam are mainly comprised of undeformed coal and cataclastic coal [19]. 
(b)

(a)
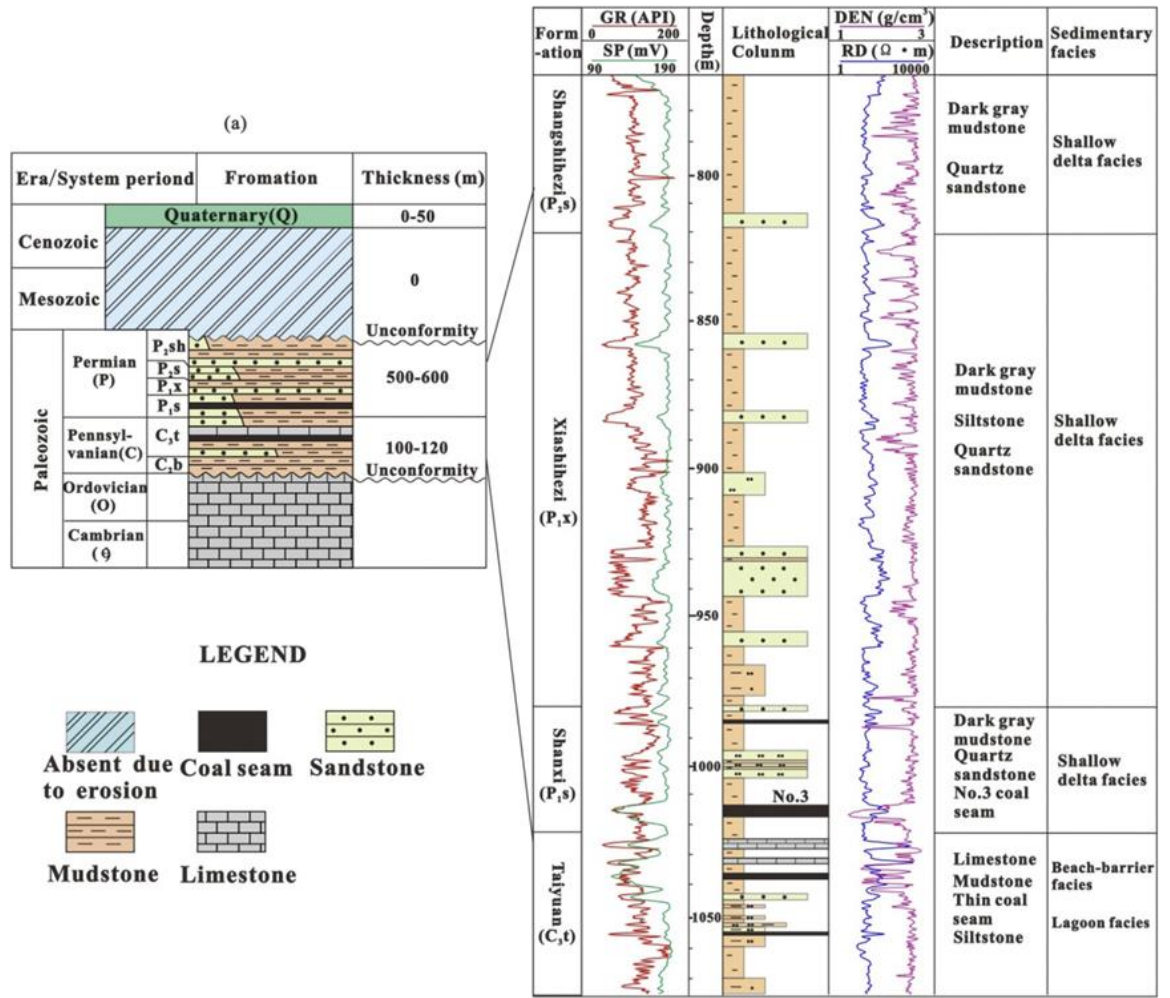

Figure 2. Stratigraphic column (a) and sedimentary characteristics of the coal-bearing strata in Zhengzhuang field (b) The data source is from well Z30 (see Figure 1 for the location). AC = acoustic logging curves; $\mathrm{C}_{2} \mathrm{~b}=\mathrm{Benxi}_{\mathrm{F}}$ Formation; $\mathrm{C}_{3} \mathrm{t}=$ Taiyuan Formation; $\mathrm{DEN}=$ density logging curve; $\mathrm{GR}=$ natural gamma-ray logging curve; $\mathrm{RD}=$ deep investigate double lateral resistivity logging curve; $\mathrm{P}_{1} \mathrm{~s}=$ Shanxi Formation; $\mathrm{P}_{1} \mathrm{x}=$ Xiashihezi Formation; $\mathrm{P}_{1} \mathrm{x}=\mathrm{Xiashihezi}$ Formation; $\mathrm{P}_{2} \mathrm{sh}=$ Shiqianfeng Formation .

\section{Data and Methodology}

\subsection{Data Preparation and Optimization of Well Logging Data}

A total of 104 cores of the No.3 coal seam were sampled from the 29 exploration wells in the study area (see locations in Figure 1). The identification of coal macrolithotypes follows the Chinese industry standard [43]. The coal samples were divided into: 35 bright coal, 39 semi-bright coal, 24 semi-dull coal, 6 dull coal. Ash compositions of these samples was also analyzed according to the Chinese industry standards [44].

Results from the description of 104 cores shows that coal macrolithotypes in the No. 3 coal seam include 35 bright, 39 semi-bright, 24 semi-dull coals, and 6 dull coals. Figure 3 illustrates examples of the macroscopic and microscopic characteristics of different coal macrolithotypes. The bright coal with steel-gray luster has well development of near-vertical cleats because of its high brittleness (Figure 3A), and it also has dominated composition of vitrinite and well development of microfractures and pores (Figure 3D). The semi-bright coal (Figure 3B) has well-developed endogenous microfractures (Figure 3E) that are partially filled with clay minerals, and it has weak mechanical strength, commonly containing thin and local-distributed vitrain bands (Figure 3C). In the semi-dull coal, some microfractures are filled with clay minerals (Figure 3F). 

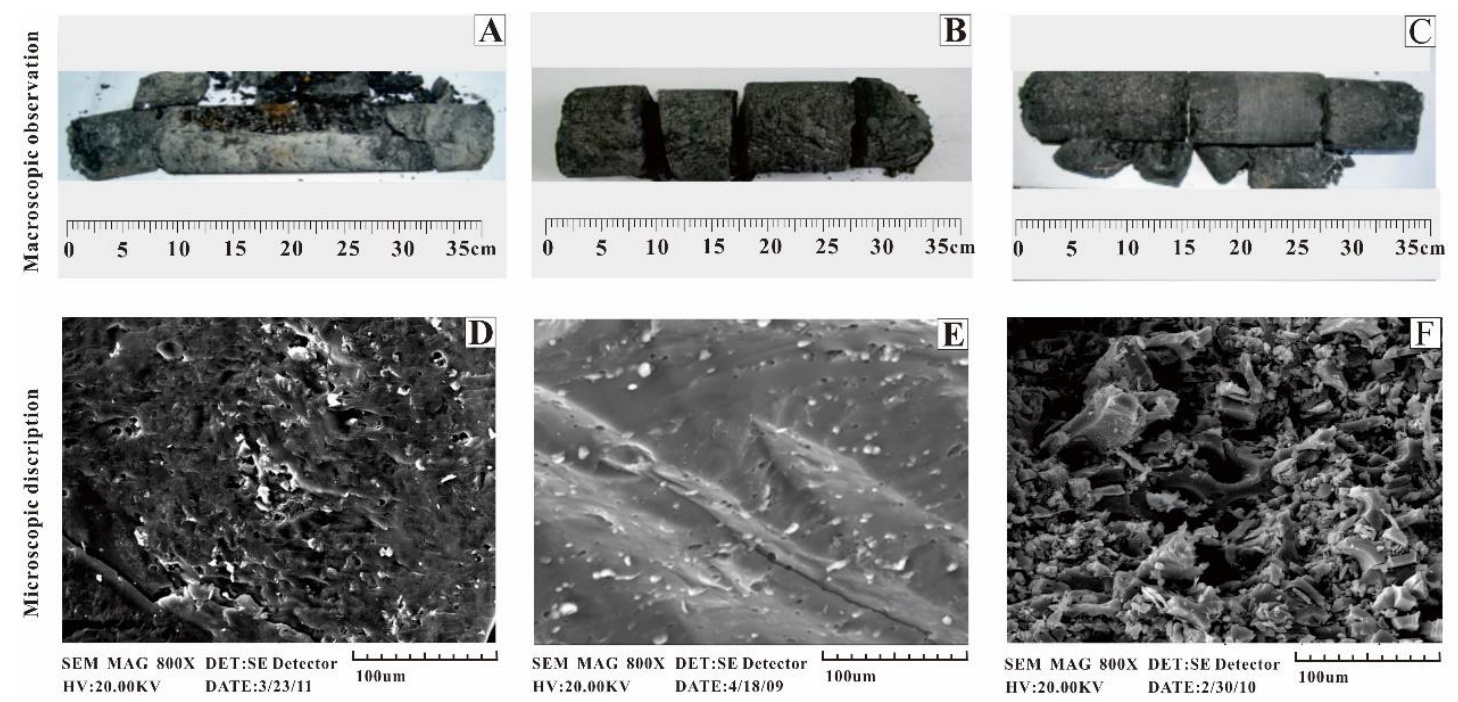

Figure 3. Typical characteristics of coals with different macrolithotypes ((A,D) bright coal; (B,E) semi-bright coal; (C,F) semi-dull coal)).

Coal macrolithotypes with different physical properties and compositions show different responses to logging data [16]. The well logging types used in the study area, mainly include DEN, AC, RT, GR, CNL (compensated neutron log), SP (spontaneous potential) and CAL (caliper log). For characterization of coal lithotypes, we did not consider the CNL, CAL, and SP, because (1) the CNL can be different in coal seam with different gas content, (2) the SP may change with different water content in the coal seam, and (3) the results of the CAL is easily affected because of borehole collapse [21]. Thus, we chose the AC, DEN, GR, and RT to classify coal lithotypes. In general, bright lithotype-rich coals (bright coal and semi-bright coal) have low DEN and high AC and RT because of the well development of pores and fractures, and commonly high gas content in bright coals) [45]. In contrast dull lithotype-rich coals (semi-dull coal and dull coal) have high ash yields, which results in a high value of GR [46].

In this study multiple logging curves (AC, DEN, GR, and RT) were comprehensive analyzed, and used to improve the identification accuracy. Before the application, the log curves were calibrated to fit the in-situ depth, whose detailed steps were explained in Fu et al. [24]. In this study, the resolution of logging data in vertical can reach $0.1 \mathrm{~m}$, and the core length is approximate $0.3 \mathrm{~m}$. Totally, 320 groups of data were obtained from 104 cores. Table 1 gives the typical logging values varying from bright coal to dull coal. With decreasing brightness, an increase of DEN, GR, and a decrease of RT and AC were found for the selected data.

Table 1. Well logging responses of macrolithotypes.

\begin{tabular}{cccccc}
\hline Lithotype & $\begin{array}{c}\text { Sample } \\
\text { Number }\end{array}$ & DEN $\left(\mathbf{g} / \mathbf{c m}^{3}\right)$ & AC $(\boldsymbol{\mu s} / \mathbf{f t})$ & GR (API) & RT $(\mathbf{\Omega} \cdot \mathbf{m})$ \\
\hline Bright coal & 35 & $1.16-1.31(1.28)$ & $401.92-489.86(438.29)$ & $25.84-75.16(45.59)$ & $661.41-6073.55(2658.18)$ \\
Semi-bright coal & 39 & $1.32-1.47(1.40)$ & $399.07-441.13(417.25)$ & $33.18-92.46(47.84)$ & $221.86-4054.65(1807.51)$ \\
Semi-dull coal & 24 & $1.45-1.61(1.51)$ & $354.57-420.29(387.32)$ & $55.69-95.92(68.07)$ & $83-1533.96(975.01)$ \\
Dull coal & 6 & $1.56-1.75(1.67)$ & $354.18-385.88(371.04)$ & $69.85-141.95(100.33)$ & $51.11-709.81(261.32)$ \\
\hline
\end{tabular}

\subsection{L-Index Identification Model by PCA Method}

In this study, PCA is adopted to convert original correlated multiple indicators into an equivalent number of independent variables. The new indicators can retain information as much as the original data, and they are manifested as a linear combination of the original several indicators [34,35]. The PCA can not only solve the problem for information overlap between the original indicators, but also can make use of the principal component 
eigenvalues to obtain objective and accurate sample composite scores by to assigning principal component scores [47].

The detailed steps of PCA are listed as follows:

Firstly, establish the original logging data matrix $X=[\mathrm{AC}, \mathrm{DEN}, \mathrm{GR} \text {, and RT }]^{T}$. There are $n$ samples and 4 variables and the matrix $X$ can be expressed as:

$$
X=\left(X_{A C}, X_{D E N}, X_{G R}, X_{R T}\right)^{T}=\left|\begin{array}{cccc}
x_{11} & x_{12} & x_{13} & x_{14} \\
x_{21} & x_{22} & x_{23} & x_{24} \\
\vdots & \vdots & \ddots & \vdots \\
x_{n 1} & x_{n 2} & x_{n 3} & x_{n 4}
\end{array}\right|
$$

Secondly, the values of four logging curves (AC, DEN, GR, and RT) were standardized to exclude the influence of the logging tools and the logging amplitude scales by using the min-max normalization method (Equation (2)). And then, the standardized matrix $Z=$ $\left[\mathrm{AC}^{\prime}, \mathrm{DEN}^{\prime}, \mathrm{GR}^{\prime} \text {, and } \mathrm{RT}^{\prime}\right]^{T}$ can be expressed as Equation (3).

$$
\begin{gathered}
\bar{x}=\frac{x-x_{\max }}{x_{\max }-x_{\min }} \\
Z=\left(X_{A C}^{\prime}, X_{D E N}^{\prime}, X_{G R}^{\prime}, X_{R T}^{\prime}\right)^{T}=\left|\begin{array}{cccc}
\overline{x_{11}} & \overline{x_{12}} & \overline{x_{13}} & \overline{x_{14}} \\
\overline{x_{21}} & \overline{x_{22}} & \overline{x_{23}} & \overline{x_{24}} \\
\vdots & \vdots & \ddots & \vdots \\
\overline{x_{n 1}} & \overline{x_{n 2}} & \overline{x_{n 3}} & \overline{x_{n 4}}
\end{array}\right|
\end{gathered}
$$

where $x$ represents the value from the original dataset, $\bar{x}$ represents the normal value, $x_{\max }$, and $x_{\min }$ represent the maximum values and minimum values of logging values in a single well reservoir; $\overline{x_{n m}}$ represents standardization data.

Then, calculate the eigenvalues of the correlation coefficient matrix $R$ by Equation (4).

$$
R=\left[r_{i j}\right]_{4 * 4}=\frac{Z^{T} Z}{n-1}
$$

where the $r_{i j}$ is the correlation coefficient between the $i$-th row and the $j$-th column of the standardization matrix $Z$ (Table 2).

Table 2. The results of correlation matrix for PCA analysis.

\begin{tabular}{ccccc}
\hline Type & DEN & AC & GR & RT \\
\hline DEN & 1.000 & -0.838 & 0.811 & -0.708 \\
AC & -0.838 & 1.000 & -0.756 & 0.689 \\
GR & 0.811 & -0.756 & 1.000 & -0.675 \\
RT & -0.708 & 0.689 & -0.675 & 1.000 \\
\hline
\end{tabular}

Next, calculate the eigenvalue $\lambda_{i}$ of the correlation coefficient matrix $R$ and the eigenvector $U_{j}(i, j,=1,2,3,4)$ by Equation (5), and ranking $\left(\lambda_{1} \geq \lambda_{2} \geq \lambda_{3} \geq \lambda_{4} \geq 0\right)$

$$
|R-\lambda U|=0
$$

In the next step, the objective information weight $W_{i}$ for each factor is obtained by Equation (6).

$$
W_{i}=\lambda_{i} / \sum_{i=1}^{4} \lambda_{i}
$$

where $\sum_{i=1}^{4} \lambda_{i}$ is the variance contribution rate. 
Finally, the PC (principal component) score is obtained by multiplying the standardized sample matrix $Z$ by a matrix $U$ consisting of the eigenvectors of the top $m$ principal components.

$$
\mathrm{F}=\mathrm{Z} \times U
$$

Logging data were further processed by a commercial software of SPSS 21 to fit these data. The statistical analyses of the correlation matrix (Table 2) indicated that when DEN is an independent variable, AC and RT decrease with increasing DEN, while the GR opposite.

From Table 3, each value of PC represents its proportion of the total variance, i.e., the preservation degree of original information. The variance contribution rate of 1st PC is $81.057 \%$ of the total variance, which indicates that effective information of the original variables can be retained as much as possible. So, we selected the 1st PC and the weight of the variable has the same value as the component score coefficient of the variable (Table 4).

Table 3. Eigenvalues and weight of principal components in PCA analysis.

\begin{tabular}{cccc}
\hline Component & $\lambda_{\boldsymbol{i}}$ & Variance (\%) & Cumulative \% \\
\hline 1st (PC) & 3.242 & 81.057 & 81.057 \\
2 & 0.362 & 9.038 & 90.095 \\
3 & 0.246 & 6.158 & 96.254 \\
4 & 0.150 & 3.746 & 100.000 \\
\hline
\end{tabular}

Table 4. Component matrix and component score coefficients.

\begin{tabular}{ccccc}
\hline Logging Curve & AC & DEN & GR & RT \\
\hline 1st PC & -0.914 & 0.935 & 0.902 & -0.848 \\
\hline
\end{tabular}

Then, an evaluation model for coal brightness determination was established as Equation (8).

$$
\mathrm{L}-\text { Index }=-0.914 \times \overline{x_{A C}}+0.935 \times \overline{x_{D E N}}+0.902 \times \overline{x_{G R}}-0.848 \times \overline{x_{R T}}
$$

where L-Index is a quantitative index for coal brightness, and the value of L-index is calculated with a vertical segment of $0.1 \mathrm{~m}$ in a whole coal seam. The $\overline{x_{A C}}, \overline{x_{D E N}}, \overline{x_{G R}}$ and $\overline{x_{R T}}$ present the standardized data for four logging parameters.

\subsection{The Relationship between L-Index and Coal Macrolithotypes}

The values of the L-Index for the whole coal seam for all CBM wells were calculated. Since the CBM wells of Z15, Z24, Z31, and Z64 have relatively complete coal core data, we select the results of the four wells (Figure 4) to compare the core observed results with the L-Index results. The red curve in Figure 4 shows the vertical change of L-Index in a whole coal seam.

Figure 5 shows the L-Index values which are calculated from the 19 core samples with the range from -97.12 to 122.14 . The L-Index values of different coal macrolithotypes and mudstone interlayer show a negative correlation with the L-Index. Thus, the coal macrolithotypes were divided into bright coal with the L-Index $(\mathrm{L}) \leq-32$, the semi-bright coal $(-32<\mathrm{L} \leq 5)$, the semi-dull coal $(5<\mathrm{L} \leq 38)$, and the dull coal $(38<\mathrm{L} \leq 82)$. The $\mathrm{L}>82$ indicates mudstone interlayer. 

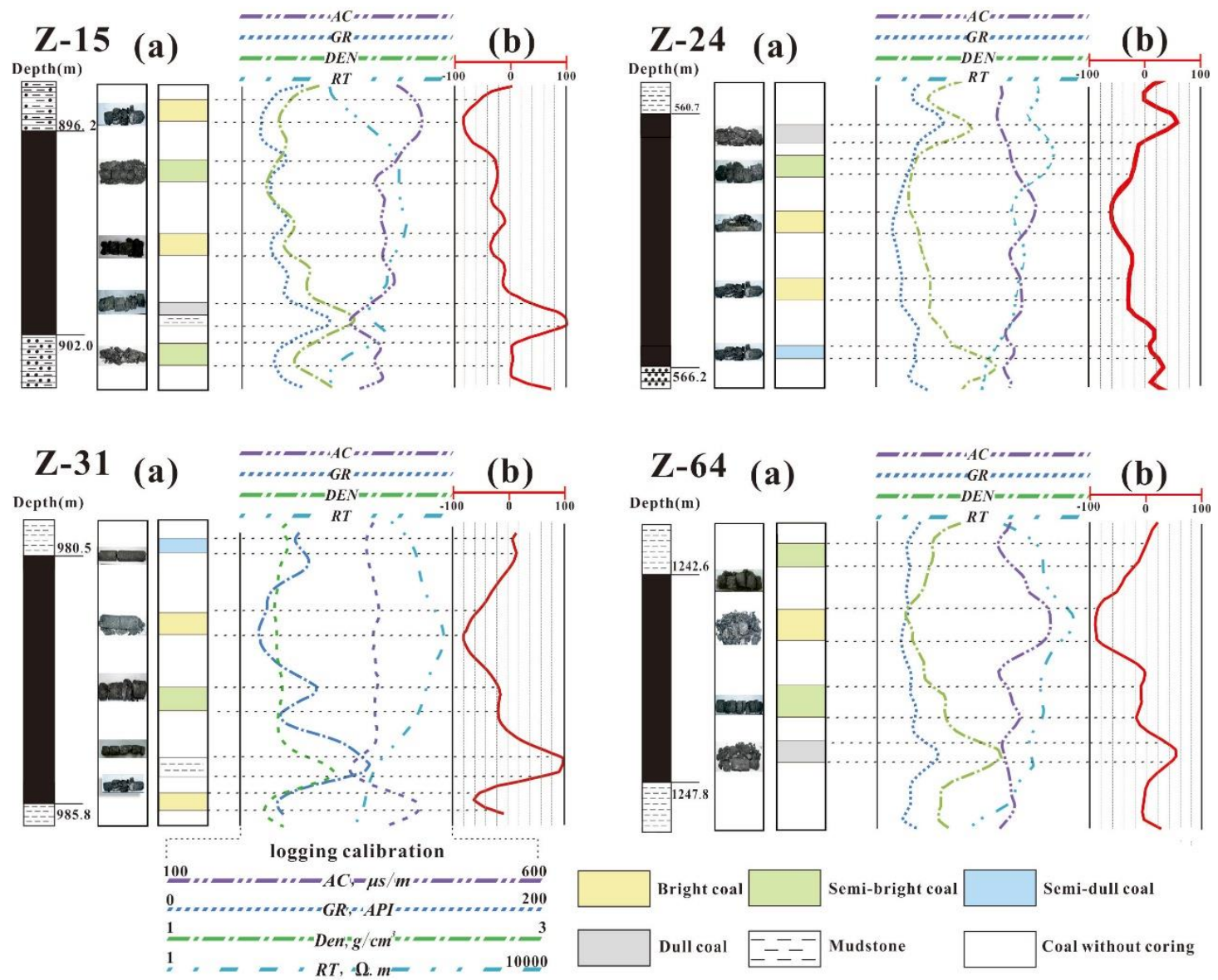

Figure 4. Vertical variations of coal macrolithotypes results identified from the core record corresponding to L-Index (a-coal cores, $\mathbf{b}$-identification by L-Index).

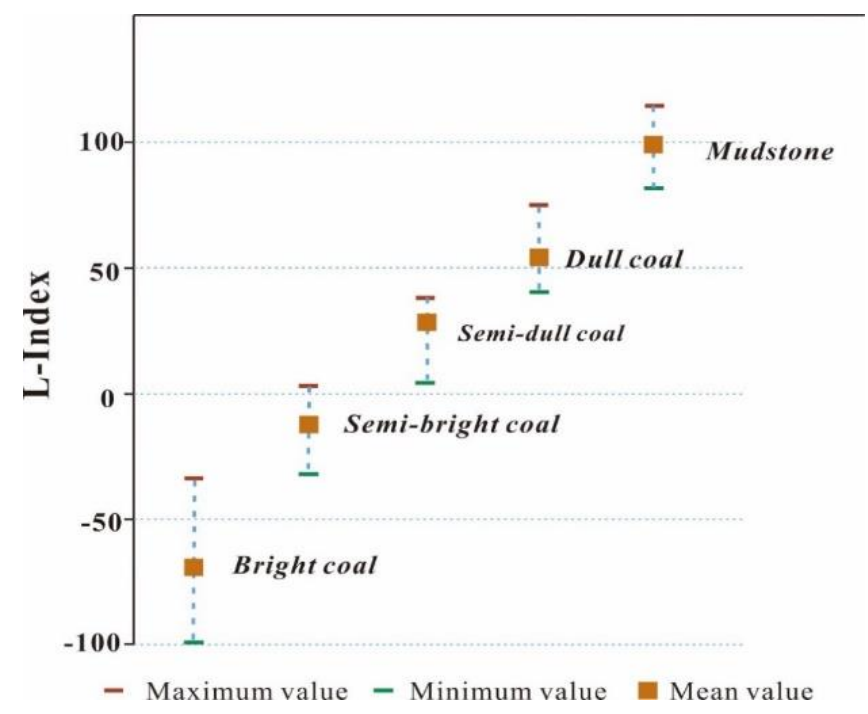

Figure 5. L-Index distribution of different coal macrolithotypes and mudstone.

\subsection{Evaluation of the Whole Coal Seam in Single Well}

Due to the differences in the thickness of the coal seam and the vertical change of coal macrolithotypes, the total brightness in a single well cannot be evaluated simply based on 
the thickness of each kind of coal macrolithotype. Thus, we proposed a new model for brightness determination in whole single well, which can be described as follows:

$$
\mathrm{S}-\text { Index }=\sum_{i=1}^{4} C_{i} T_{i} / T_{\text {net }}
$$

where S-Index is a weighting sum of the four macroscopic coal macrolithotypes, a larger S-Index value indicating a lower coal brightness of the whole coal seam; $i$ corresponds to coal macrolithotype type (1, 2, 3, and 4 for bright, semi-bright, semi-dull and dull coal, respectively); $C_{i}$ represent the weighting coefficients of coal macrolithotype of the total thickness of No. 3 coal seam; $T_{\text {net }}$ represents the total net thickness of coal in a single well.

The $C_{i}$ can be calculated by Equation (10).

$$
C_{i}=1+\sum P_{i-1}(4-1)
$$

where, $P_{i}$ represents the proportion of coal thickness, and the $P_{0}$ is defined as a value of 0 . The calculated $C_{i}$ values are given in Table 5 .

Table 5. Weight coefficient assignments for different coal macrolithotypes.

\begin{tabular}{ccccccc}
\hline Coal Macrolithotype & Net Coal & Bright & Semi-Bright & Semi-Dull & Dull & Mudstone \\
\hline Type & $/$ & I & II & III & IV & $/$ \\
Thickness $(m)$ & 350.5 & 97.2 & 173.7 & 46.7 & 32.9 & 42 \\
Proportion $\left(P_{i}\right)$ & $100 \%$ & $27.73 \%$ & $49.56 \%$ & $13.32 \%$ & $9.39 \%$ & $/$ \\
Weight coefficient $\left(C_{i}\right)$ & $/$ & 1.0 & 1.8 & 3.3 & 3.7 & $/$ \\
\hline
\end{tabular}

Then, the equation of S-index is given as follows:

$$
\mathrm{S}-\text { Index }=\left(1.0 \times T_{I}+1.8 \times T_{2}+3.3 \times T_{3}+3.7 \times T_{4}\right) / T_{n e t}
$$

The S-Index is defined as a value from 1 to 3.7: smaller S-Index indicating higher degree of brightness. According to Equation (11), we calculated S-Index isovalue map in the Zhengzhuang field. For example, the S-Index of the well Z15 is 1.90, and the coal macrolithotypes of the well are dominated by bright and semi-bright coal. In contrast, for the well Z47 whose S-Index equals to 2.84, the proportion of semi-dull coal and dull coal is as high as $38 \%$.

\section{Result and Discussion}

\subsection{Verification of the L-Index Model}

This section will report the verification of the proposed L-Index model. Two CBM wells (Z36 and Z66) that were not subjected in the model construction, were selected for this verification. As shown in Figure 6, the coring identification results agree well the logging prediction results in most cases ( $>98 \%$ accuracy). However, there are also some exceptions. For example: a $0.2 \mathrm{~m}$-long section of dull coal was identified as semi-dull coal at the bottom of Well Z36 and a $0.1 \mathrm{~m}$-long section at a depth of $1075 \mathrm{~m}$ was mistaken as semi-dull coal in Well Z36. The existence of this discrepancy is likely because of transition boundaries and/or the lower longitudinal resolution of the logging data [19]. In general, we assume the present method is better than many exist methods, and the method is applicable for identifying coal macrolithotype in the study area. 

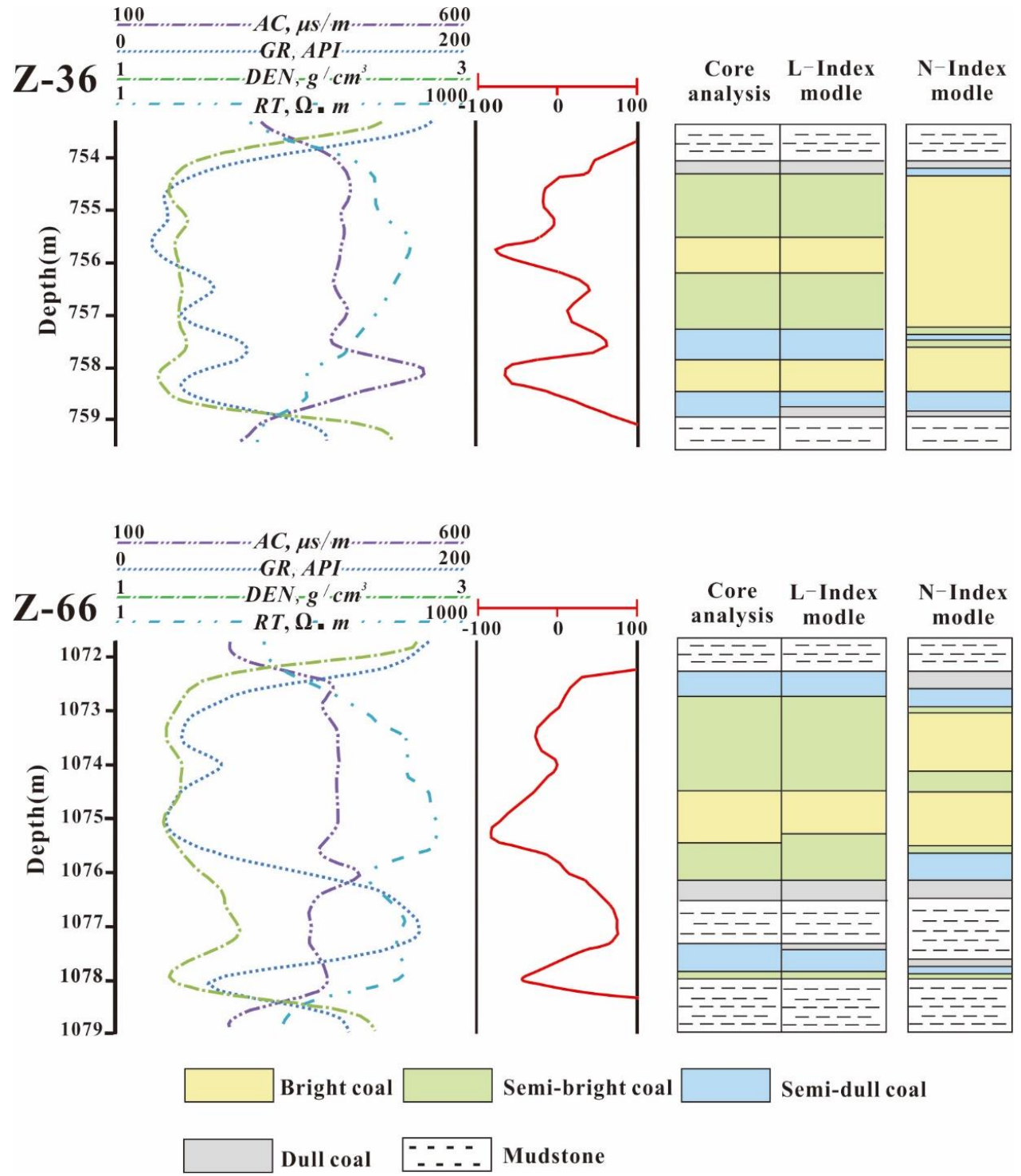

Figure 6. Comparison of results of coal macrolithotype identifications based on core analysis and the well logging interpretations for Well Z36 and Well Z66. The logging interpretations based on both the L-index model in this study and N-index model from Tao et al., 2019 [16], are presented.

To best of the authors' knowledge, this is the first time that the empirical indexes (L-Index and S-Index) were proposed to predict the coal macrolithotypes in a whole coal seam. However, there were reports relating to the quantification of coal lithotypes of a segment of coal seam based on logging responses. For example, Tao et al. [16] ever provided a logging model for predicting coal lithotypes. In Tao et al.'s model, they used the $\mathrm{N}$-index (equal to $\mathrm{AC} /(\mathrm{DEN} \times \mathrm{GR})$ ) to identify different coal macrolithotypes of a segment of coal seam: $\mathrm{N} \leq 1.3,1.3<\mathrm{N} \leq 3,3<\mathrm{N} \leq 5,5<\mathrm{N} \leq 8$, and $\mathrm{N}>8$, corresponding to parting, dull coal, semi-dull coal, semi-bright coal, and bright coal, respectively. To compare the predicted results based on L-index model with those based on N-index model from Tao et al., 2019 [16], we put the results from two models in Figure 6. As shown in Figure 6, the predicted results of $\mathrm{N}$-index model have certain errors especially for the identification between bright coal and semi-bright coal. Compared with the N-Index model, L-Index model added the RT logging curve which related to the different fracture density of coal macrolithotypes. Meanwhile, the PCA method can improve the efficiency of the correlated logging curves parameters for evaluation. Thus, the L-Index model is better than N-Index model, and the method is applicable for identifying coal macrolithotype in the study area. 


\subsection{Vertical Distributions of Coal Macrolithotypes}

Based on the L-Index method mentioned in Section 3.3, the vertical distributions of macrolithotypes in No.3 coal seam were investigated. Two typical cross-sections of the A- $\mathrm{A}^{\prime}$ and B-B' sections are presented in Figure 7.

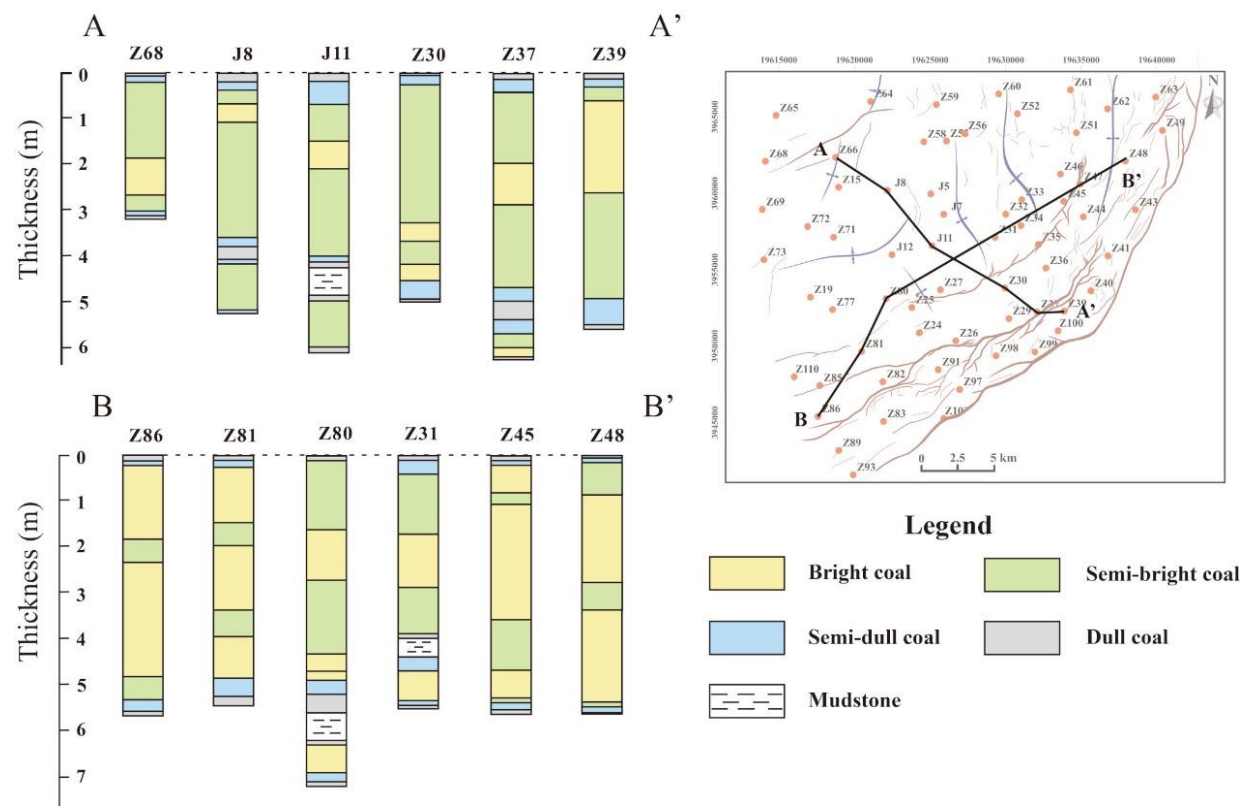

Figure 7. $\mathbf{A}$ to $\mathbf{A}^{\prime}$ and $\mathbf{B}$ to $\mathbf{B}^{\prime}$ cross-sections showing No. 3 seam thickness and macrolithotype identification from the well logging data.

The A- $\mathrm{A}^{\prime}$ cross-section is approximately located along the dip of the coal seam in the NE-SW direction, consisting wells of Z68, J8, J11, Z30, Z37 and Z39. The thickness of No. 3 coal seam in the research region is of 3.5-7.1 m. In the A-A' cross-section, the coal seam is dominated by semi-bright coals, followed by bright coals, and semi-dull and dull coals are thinnest locally distributed in the top and bottom seam.

The B-B' section is approximately located along the dip of the coal seam in the NW-SE direction, consisting wells of Z86, Z81, Z80, Z31, Z45 and Z48. In the B-B' cross-section, the coal seam is dominated by bright coal in the central part of the study area, and the semi-bright coal is only distributed in the northeast and southwest areas. Like the A-A', the sub-layer of the semi-dull and dull coal are mainly located in both the upper and lower parts of the coal seam, whereas bright and semi-bright coal are present in the middle parts of the coal seam.

It is also found that the intermittently-developed mudstone interlayers with $0.3-0.7 \mathrm{~m}$ thickness are in the lower part of the coal seam for well of J11, Z80 and Z31, in the central part of the Zhengzhuang field. The logging response of the mudstone interlayer is influenced by the mud content, in which the GR value of this part increases rapidly (139-225 API).

\subsection{Regional Distribution of Coal Macrolithotypes}

The regional distributions of coal macrolithotypes in the Zhengzhuang field are shown in Figs. 8. In general, the Zhengzhuang field is dominated by bright and semi-bright coals with thicknesses ranging from 2 to $5.6 \mathrm{~m}$ with an average of $4.2 \mathrm{~m}$. The thickness of bright coal ranges from $0.3 \mathrm{~m}$ to $4.1 \mathrm{~m}$ with an average value of $1.6 \mathrm{~m}$. Bright coal with a thickness of $\geq 3.2 \mathrm{~m}$ is distributed in the southwest, southeast, and northeast of the study area (Figure 8a). In contrast, bright coal with thickness of $<0.5 \mathrm{~m}$ is in the northwest, central and north areas. As for semi-bright coal, it ranges from $0.8 \mathrm{~m}$ to $4.3 \mathrm{~m}$ with an average of $2.7 \mathrm{~m}$ (Figure $8 \mathrm{~b}$ ). It is mainly distributed in the central part and the northeastern area with a thickness exceeding 
$2.8 \mathrm{~m}$, but it has a thickness no more than $1.3 \mathrm{~m}$ in the southwestern and southeastern area. The thickness of semi-dull coal ranges from $0.3 \mathrm{~m}$ to $1.8 \mathrm{~m}$ with an average of $0.7 \mathrm{~m}$ (Figure $8 \mathrm{c}$ ). The semi-dull coal is mainly distributed in the central and southeastern regions. In the case of dull coal, it is widely distributed in the northern and southern regions with a thickness range of $0.1-1.1 \mathrm{~m}$ (Figure $8 \mathrm{~d}$ ).

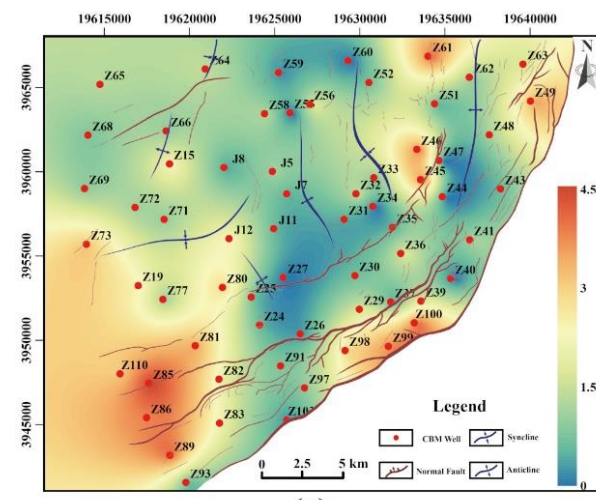

(a)

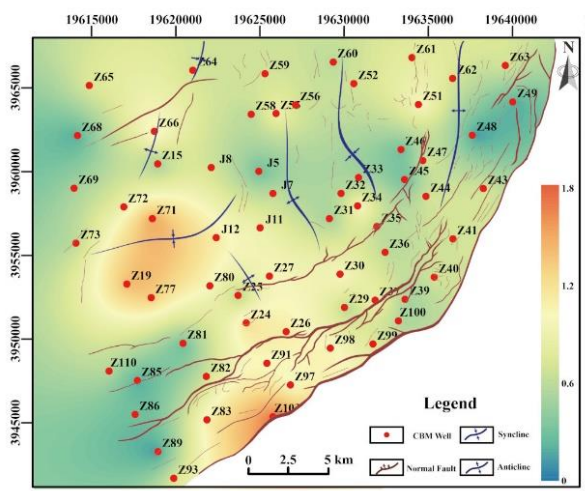

(c)

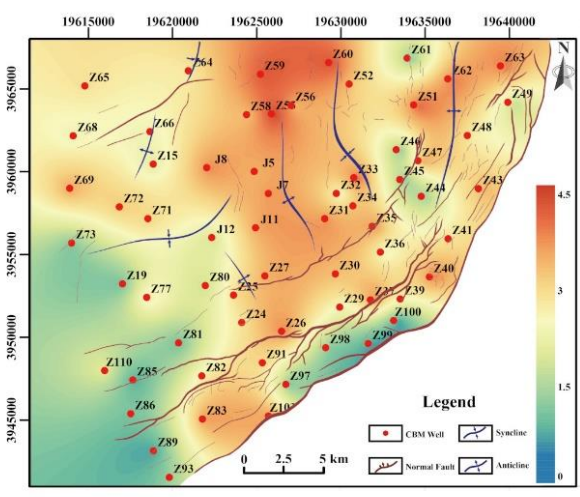

(b)

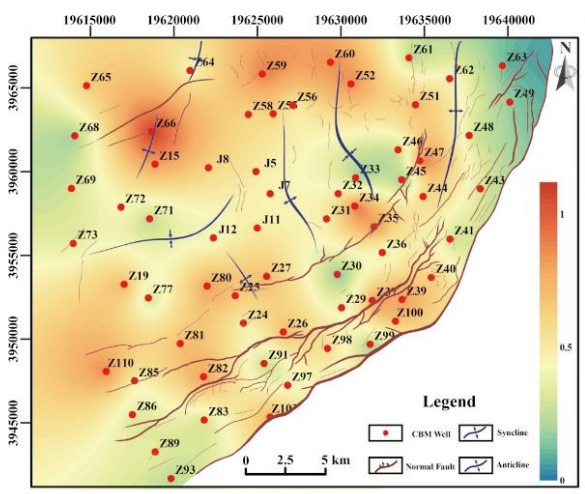

(d)

Figure 8. Isopach map of different macrolithotypes of the No. 3 coal seam in the Zhengzhuang field. ((a-d) represent bright coal, semi-bright coal, semi-dull coal and dull coal).

The coal macrolithotypes distribution is controlled by the organic matters input and sedimentary environment, which can be utilized to reconstruct the paleoenvironment of peat swamps [18]. For example, the vitrinite to inertinite ratio (V/I) can intuitively reflects the swamp water cover degree, because typically, vitrinite formed in a relative moist reducing environment coupled with gelatinization, while the inertinite formed in a relative dry oxidizing environment due to the dominating fusainization. In the Zhengzhuang field, the northern, western, and eastern area has V/I values ranging from 1.2 to 2.7, which reflects the moist water covered environments, the central, northeastern, and southwestern area have the $\mathrm{V} / \mathrm{I}$ ranging from 2.7 to 4 illustrating the moist-deep water covered environments, and the locally southeastern area has the $\mathrm{V} / \mathrm{I}<1$ reflecting dry shallow water covered environment. Corresponding to the distributions of the coal macrolithotypes (Figure 9), bright coal and semi-bright coal are formed in the moist-deep water covered and moist water covered environments respectively, and semi-dull coal and dull coal are usually formed in the dry shallow water covered environment. 


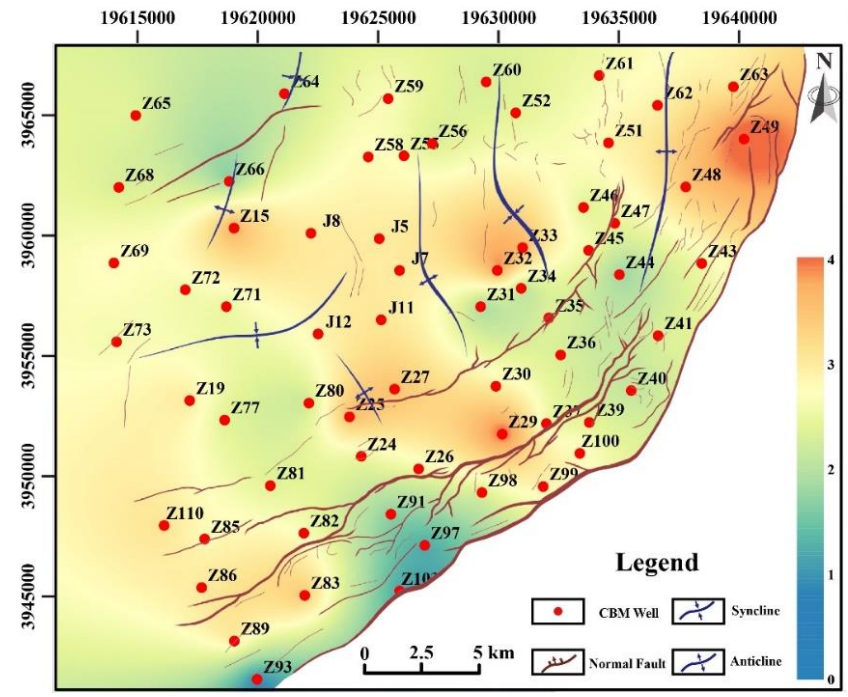

Figure 9. V/I isovalue map of the No.3 coal seam in the Zhengzhuang field ( $\mathrm{V}=$ vitrinite, $\mathrm{I}=$ Inertinite).

\subsection{Influence of Coal Macrolithotype on Fracturing Efficiency}

Hydraulic fracturing has been widely adopted in the CBM exploitation, and the fracturing efficiency is influenced by several factors such as hydraulic fracture design and reservoir geologic characteristics [8]. The difference of coal macrolithotypes can control the fracture extension and distribution which influence the final fracturing effect. Fracture length and fracture height are critical parameters to evaluate the hydraulic fracturing effect of CBM reservoir [48]. In this section, the S-Index quantifying the total brightness of a single CBM well was used to investigate the relationships between the total brightness of coal seam and the final fracturing effects.

Figure 10 include the S-Index isovalue map and the characteristics of hydraulic fracture. The S-Index values of Zhengzhuang field is within the range from 1.35 to 2.85 with an average of 1.99 , which means that bright coal and semi-bright coal take a large proportion in this region.

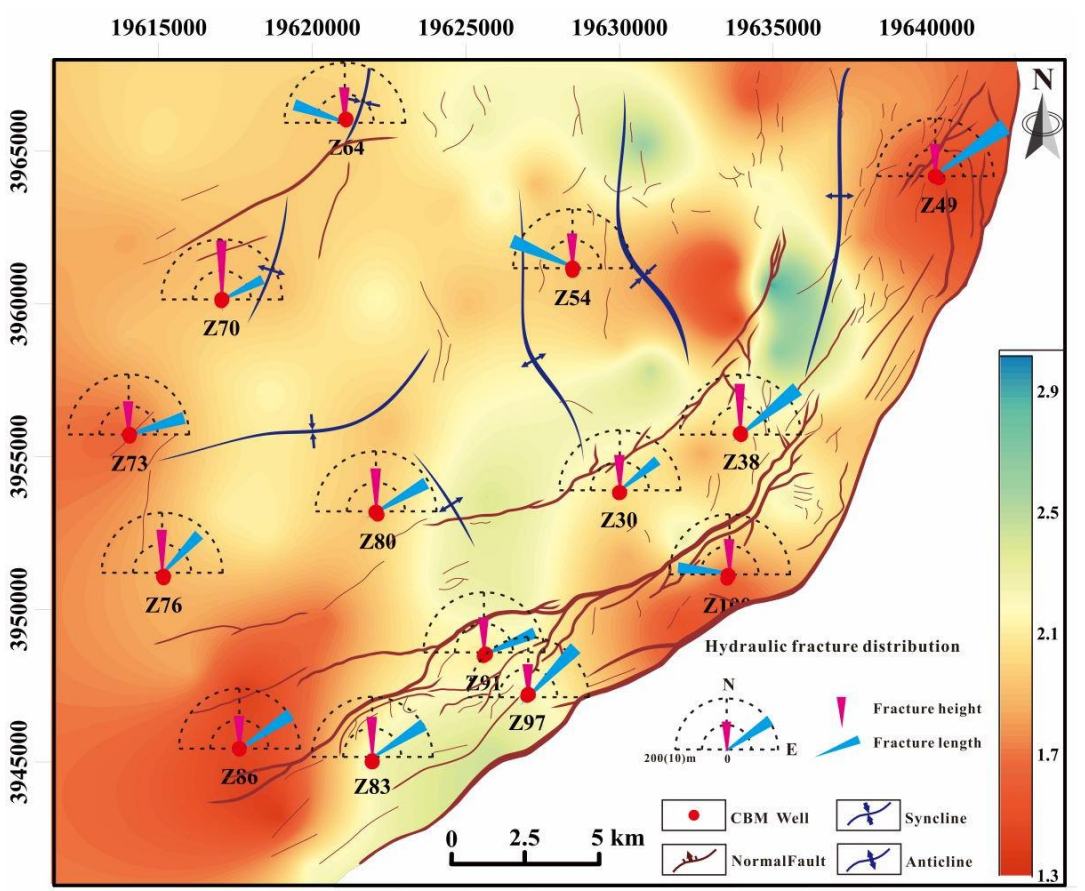

Figure 10. S-Index isovalue map of the No. 3 coal seam in the Zhengzhuang field. 
Based on the analysis of microseismic data in this region, we obtained the hydraulic fracture propagation of 14 wells (Table 6). Results show that the length and height of the major fractures range from 142.0 to $260.0 \mathrm{~m}$ and 6.0 to $9.8 \mathrm{~m}$, respectively. Figure 11a,b reveal the relationship between S-Index and hydraulic fracturing fractures in the No. 3 coal seam. The fitting chart shows that the fracture height and length are positively and negatively correlated with the S-Index, respectively.

Table 6. Hydraulic fractures distribution of some wells in study area.

\begin{tabular}{cccccccccc}
\hline Well & S-Index & Length $(\mathbf{m})$ & Height $(\mathbf{m})$ & Direction $\left({ }^{\circ}\right)$ & Well & S-Index & Length $(\mathbf{m})$ & Height $(\mathbf{m})$ & Direction $\left({ }^{\circ}\right)$ \\
\hline Z30 & 2.16 & 152.0 & 6.7 & NE56.2 & Z76 & 1.80 & 187.8 & 7.4 & NE41.0 \\
Z38 & 2.17 & 218.7 & 8.0 & NE52.8 & Z80 & 1.92 & 216.7 & 6.8 & NE40.0 \\
Z49 & 1.41 & 260.0 & 6.0 & NE50.0 & Z83 & 2.23 & 195.1 & 7.4 & NE67.0 \\
Z54 & 1.80 & 221.3 & 6.7 & NW56.5 & Z86 & 1.45 & 202.7 & 6.5 & NE54.5 \\
Z64 & 1.94 & 170.7 & 6.7 & NW76.0 & Z91 & 2.07 & 181.4 & 7.5 & NE60.2 \\
Z70 & 2.39 & 142.0 & 9.8 & NE51.0 & Z97 & 2.12 & 220.9 & 5.7 & NE42.0 \\
Z73 & 1.62 & 197.7 & 6.5 & NE72.0 & Z100 & 1.71 & 178.0 & 6.7 & NW85.0 \\
\hline
\end{tabular}
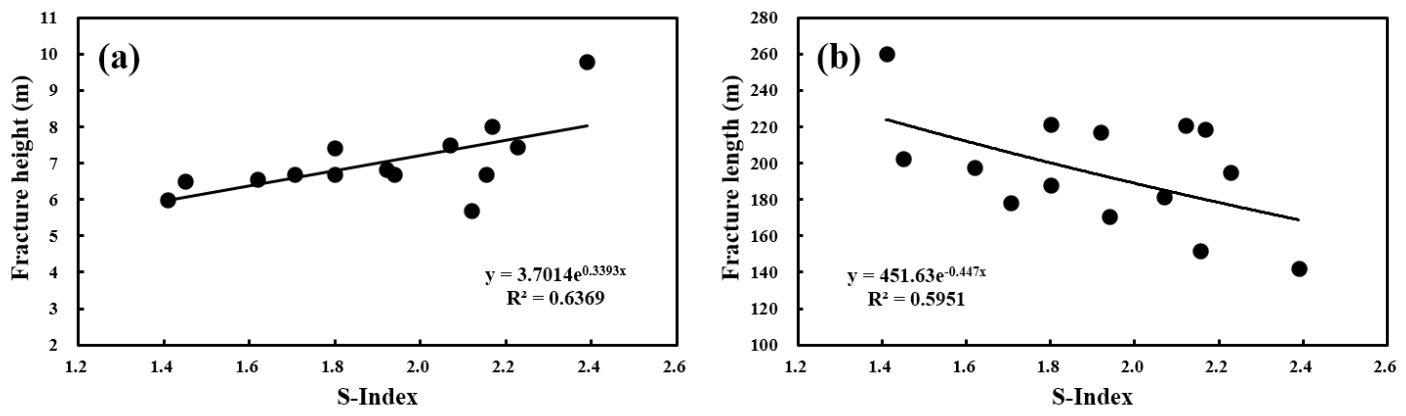

Figure 11. Relationship between S-Index and fracturing efficiency. (a) Relationship between S-Index and fracture height. (b) Relationship between S-Index and fracture length.

Figure 12 and Table 7 illustrate that the compressive strength, tensile strength, and elasticity modulus increase, while the Poisson's ratio decrease with increasing S-Index. Compared with the dull lithotype-rich coal, the bright lithotype-rich coal seam has low mechanical strengths (low compressive strength, low tensile strength, low elasticity modulus and high Poisson's ratio high Poisson's ratio). The dull lithotype-rich coals having higher tensile strength are hard to be broken, and are favorable for forming short fracture during hydro-fracturing. In contrast, the bright lithotype-rich coal has lower elasticity modulus so that it is easy to be broken. Meanwhile, the bright lithotype-rich coal is easily to form stress concentration at the fracture tip, which is favorable for extension of long fractures. Thus, the long and wide hydro-fractures are easily formed in the bright lithotype-rich coal.

There is another situation for hydro-fracturing of coal seam with different coal lithotypes. For the coal seam with dominating bright lithotype-rich coal, the differences of mechanical strength between the coal seam and the roof/floor rocks (mudstones or siltstones in the study area) are relatively large, which is favorable to constraint the hydrofracture within the coal seam. In contrast, the coal seam with dominating dull lithotype-rich coals commonly has similar mechanical strength with the roof/floor rocks, and thus the hydro-fracture is easy to break through the roof or/and floor of the coal seam during the hydro-fracturing process, which is unfavorable for fracturing effect. 
Table 7. Rock mechanical characteristics of coal and coal roof and floor.

\begin{tabular}{|c|c|c|c|c|c|c|c|c|c|c|c|}
\hline Well & S-Index & $\begin{array}{l}\text { Compressive } \\
\text { Strength (Mpa) }\end{array}$ & $\begin{array}{c}\text { Tensile } \\
\text { Strength (Mpa) }\end{array}$ & $\begin{array}{c}\text { Elasticity } \\
\text { Modulus (Mpa) }\end{array}$ & $\begin{array}{l}\text { Poisson's } \\
\text { Ratio }(\mu)\end{array}$ & Well & S-Index & $\begin{array}{l}\text { Compressive } \\
\text { Strength (Mpa) }\end{array}$ & $\begin{array}{c}\text { Tensile } \\
\text { Strength (Mpa) }\end{array}$ & $\begin{array}{c}\text { Elasticity } \\
\text { Modulus (Mpa) }\end{array}$ & $\begin{array}{l}\text { Poisson's } \\
\text { Ratio }(\mu)\end{array}$ \\
\hline Z19 & 1.90 & / & / & 0.9 & 0.33 & Z76 & 1.80 & 14.52 & 0.65 & 1.17 & 0.32 \\
\hline $\mathrm{Z} 30$ & 2.16 & 20.91 & / & 1.63 & 0.3 & $\mathrm{Z78}$ & 2.11 & 12.28 & 0.55 & 1.22 & 0.32 \\
\hline $\mathrm{Z} 54$ & 1.80 & 8.64 & 0.33 & 0.75 & 0.33 & Z80 & 1.92 & 17.41 & 0.78 & 1.52 & 0.31 \\
\hline $\mathrm{Z} 55$ & 2.22 & 28.45 & 1.2 & 2.33 & 0.3 & Z82 & 1.96 & 14.18 & 0.75 & 1.21 & 0.31 \\
\hline Z64 & 1.94 & 11.51 & 0.5 & 1.12 & 0.33 & $\mathrm{Z} 91$ & 2.07 & 17.68 & 0.76 & 1.43 & 0.32 \\
\hline $\mathrm{Z70}$ & 2.39 & 12.41 & 0.53 & 1.07 & 0.32 & Z97 & 2.12 & 14.91 & 0.65 & 1.15 & 0.33 \\
\hline $\mathrm{Z73}$ & 1.62 & 9.3 & 0.42 & 0.78 & 0.33 & Z103 & 2.41 & 18.38 & 0.85 & 1.59 & 0.31 \\
\hline
\end{tabular}



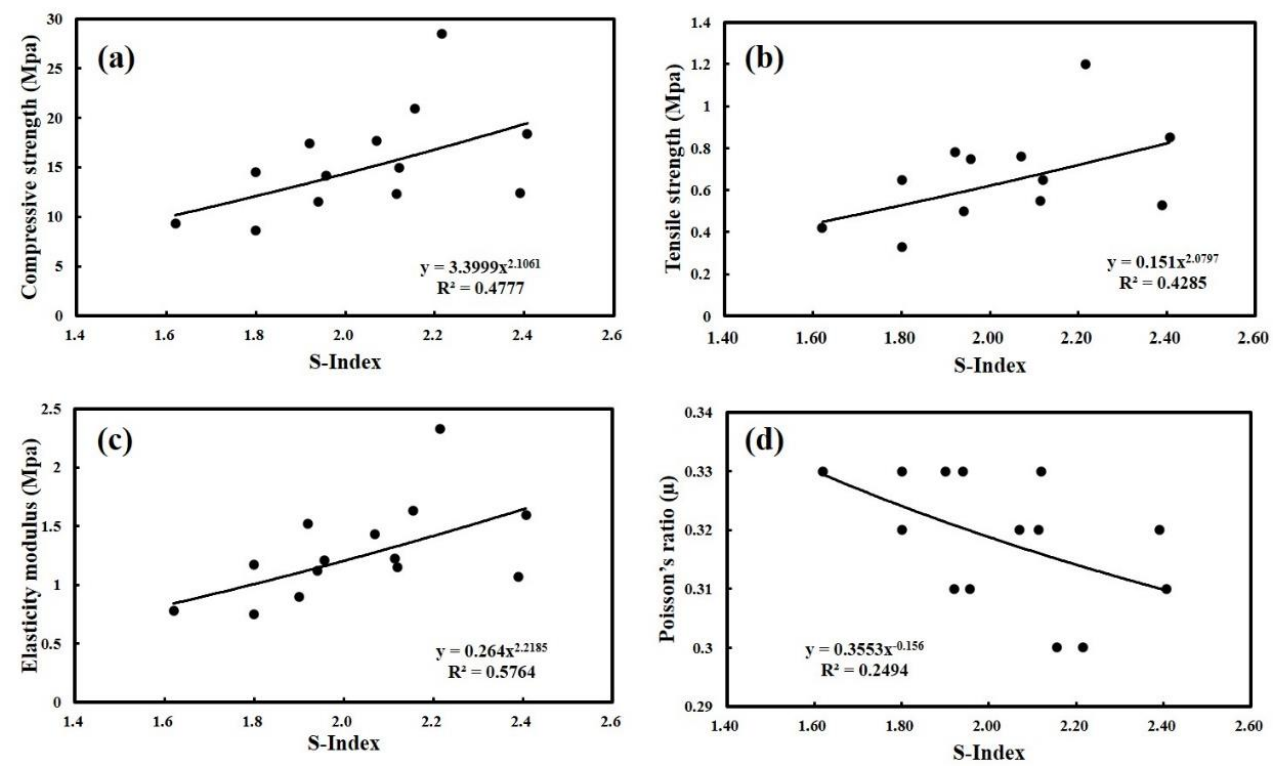

Figure 12. Relationship between S-Index and coal rock mechanics parameters. (a) Relationship between S-Index and compressive strength. (b) Relationship between S-Index and tensile strength. (c) Relationship between S-Index and elasticity modulus. (d) Relationship between S-Index and Poisson's ratio.

Based on the above analysis, the coal seam with low S-Index values can easily form long extending fractures during hydraulic fracturing. The long fractures can connect which far from the wellbore in the bright coal seam and thus can directly improve the production of the CBM well. Therefore, the reservoir with low S-Index is favorable for hydro-fracturing.

In general, the proposed coal macrolithotype evaluation method is applicable to identify macrolithotype of coal seams by using small amount of coring samples. Moreover, the S-Index can provide a reference for CBM exploration: a smaller S-Index value indicating a higher coal brightness and a better potential for CBM exploration. However, the limitation of this method is that the model was derived from the anthracite coals in Zhengzhuang field, and it is uncertainty that this method can be applied to other CBM fields where the coals belong to lignite or bituminous coals.

\section{Conclusions}

Traditional methods for coal macrolithotype evaluation often rely on core observation, which is non-economical and insufficient for field application. In this study, we proposed a new logging-based coal macrolithotype evaluation method that was further applied for the prediction of coal macrolithotypes in the Zhengzhuang field. The main achievements as follow:

A coal macrolithotype identification method is established based on the L-index derived from a PCA on four logs, AC, DEN, GR and RT. Four L-Index intervals are used to classify coal macrolithotype in a segment of coal seam: $\mathrm{L} \leq-32$ for bright coal, $-32<\mathrm{L} \leq 5$ for semi-bright coal, $5<\mathrm{L} \leq 38$ for semi-dull coal, and $38<\mathrm{L} \leq 82$ for dull coal. Another parameter, the S-Index is proposed to quantify coal seam brightness of whole single well: a larger S-Index value indicating a lower seam coal brightness.

In the Zhengzhuang field, vertically, the macrolithotypes of No. 3 coal seam are dominated by the bright coal and semi-bright coal, while the semi-dull coal and dull coal are thinner distributed in the top and bottom coal seam, and the intermittently-developed mudstone interlayers with $0.3-0.7 \mathrm{~m}$ thickness in the lower part of the studied coal seam. Regionally, the macrolithotypes are dominated by the bright and semi-bright coal, with a thickness of $2-5.6 \mathrm{~m}$. 
Compared with dull lithotype-rich coal seam, the bright lithotype-rich coal seam is favorable for the development of long hydro-fractures within coal seam during the process of hydro-fracturing, because the has bright lithotype-rich coal seam low mechanical strengths (e.g., low tensile strength and high Poisson's ratio). The bright lithotype-rich coal seam has high gas production potential than the dull lithotype-rich coal seam.

This method can provide a reference for the quantitative identification of coal macrolithotypes of medium-to-low volatile bituminous coals and anthracite coals reservoirs in other CBM fields.

Author Contributions: Y.Y.: Conceptualization, Supervision, Writing Reviewing and Editing. C.C.: Methodology, Validation, Writing Original draft preparation, Investigation. S.C., Project administration, Funding acquisition, Resources. L.C.: Methodology, Investigation. All authors have read and agreed to the published version of the manuscript.

Funding: This study was supported by the National Natural Science Foundation of China (41830427; 41872123), the National Major Science and Technology Projects of China (2016ZX05043-001), the Key Research and Development Project of the Xinjiang Uygur Autonomous Region (2017B03019-1), and the unveiling projects of the Department of Science and Technology of Shanxi Province (20191101018).

Institutional Review Board Statement: Not applicable.

Informed Consent Statement: Not applicable.

Data Availability Statement: Not applicable.

Acknowledgments: We acknowledge financial support from the National Natural Science Foundation of China (41830427; 41872123), the National Major Science and Technology Projects of China (2016ZX05043-001), and the Key Research, Development Project of the Xinjiang Uygur Autonomous Region (2017B03019-1), and the unveiling projects of the Department of Science and Technology of Shanxi Province (20191101018).

Conflicts of Interest: The authors declare no conflict of interest.

\section{References}

1. Fu, X.H.; Qin, Y.; Wang, G.G.X.; Rudolph, V. Evaluation of coal structure and permeability with the aid of geophysical logging technology. Fuel 2009, 88, 2278-2285. [CrossRef]

2. Cao, L.T.; Yao, Y.B.; Cui, C.; Sun, Q.P. Characteristics of in-situ stress and its controls on coalbed methane development in the southeastern Qinshui Basin, North China. Eng. Geosci. 2020, 1, 69-80.

3. Yao, Y.B.; Liu, D.M.; Tang, D.Z.; Tang, S.H.; Huang, W.H. Fractal characterization of adsorption-pores of coals from North China: An investigation on $\mathrm{CH}_{4}$ adsorption capacity of coals. Int. J. Coal Geol. 2008, 73, 27-42. [CrossRef]

4. Zheng, S.J.; Yao, Y.B.; Liu, D.M.; Cai, Y.D.; Liu, Y. Characterizations of full-scale pore size distribution, porosity and permeability of coals: A novel methodology by nuclear magnetic resonance and fractal analysis theory. Int. J. Coal Geol. 2018, 196, 148-158. [CrossRef]

5. Karacan, C.O.; Ruiz, F.A.; Cotè, M.; Phipps, S. Coal mine methane: A review of capture and utilization practices with benefits to mining safety and to greenhouse gas reduction. Int. J. Coal Geol. 2011, 86, 121-156. [CrossRef]

6. Wang, Y.J.; Liu, D.M.; Cai, Y.D.; Yao, Y.B.; Zhou, Y.F.J. Evaluation of structured coal evolution and distribution by geophysical logging methods in the Gujiao Block, northwest Qinshui basin, China. Nat. Gas. Sci. Eng. 2018, 51, 210-222. [CrossRef]

7. Su, X.B.; Lin, X.Y.; Zhao, M.J.; Song, Y.; Liu, S.B. The upper Paleozoic coalbed methane system in the Qinshui basin, China. AAPG Bull. 2005, 89, 81-100. [CrossRef]

8. Cao, L.T.; Yao, Y.B.; Liu, D.M.; Yang, Y.H.; Wang, Y.J.; Cai, Y.D. Application of seismic curvature attributes in the delineation of coal texture and deformation in Zhengzhuang field, southern Qinshui Basin. AAPG Bull. 2020, 104, 1143-1166. [CrossRef]

9. Jiang, B.; Qu, Z.H.; Wang, G.G.X. Effects of structural deformation on formation of coalbed methane reservoirs in Huaibei coalfield, China. Int. J. Coal Geol. 2010, 82, 175-183. [CrossRef]

10. Tao, S.; Tang, D.Z.; Xu, H.; Gao, L.J.; Fang, Y. Factors controlling high-yield coalbed methane vertical wells in the Fanzhuang Block, Southern Qinshui Basin. Int. J. Coal Geol. 2014, 134, 38-45. [CrossRef]

11. Clarkson, C.R.; Bustin, R.M. Variation in micropore capacity and size distribution with composition in bituminous coal of the Western Canadian Sedimentary Basin: Implications for coalbed methane potential. Fuel 1996, 75, 1483-1498. [CrossRef]

12. Connell, L.D.; Lu, M.; Pan, Z.J. An analytical coal permeability model for tri-axial strain and stress conditions. Int. J. Coal Geol. 2010, 84, 103-114. [CrossRef]

13. O'Keefe, J.M.K.; Bechtel, A.; Christanis, K.; Dai, S.F.; DiMichele, W.A.; Eble, C.F.; Esterle, J.S.; Mastalerz, M.; Raymond, A.L.; Valentim, B.V.; et al. On the fundamental difference between coal rank and coal type. Int. J. Coal Geol. 2013, 118, 58-87. [CrossRef] 
14. Ramandi, H.L.; Mostaghimi, L.; Armstrong, R.T.; Saadatfar, M.; Pinczewski, W.V. Porosity and permeability characterization of coal: A micro-computed tomography study. Int. J. Coal Geol. 2016, 154, 57-68. [CrossRef]

15. Zhao, J.L.; Xu, H.; Tang, D.Z.; Mathews, J.P.; Li, S.; Tao, S. Coal seam porosity and fracture heterogeneity of macrolithotypes in the Hancheng Block, eastern margin, Ordos Basin, China. Int. J. Coal Geol. 2016, 159, 18-29. [CrossRef]

16. Tao, S.; Pan, Z.J.; Chen, S.D.; Tang, S.L. Coal seam porosity and fracture heterogeneity of marcolithotypes in the Fanzhuang Block, southern Qinshui Basin, China. J. Nat. Gas Sci. Eng. 2019, 66, 148-158. [CrossRef]

17. Karacan, C.O.; Mitchell, G.D. Behavior and effect of different coal microlithotypes during gas transport for carbon dioxide sequestration into coal seams. Int. J. Coal Geol. 2003, 53, 201-217. [CrossRef]

18. Zhang, S.H.; Tang, S.H.; Tang, D.Z.; Pan, Z.J.; Yang, F. The characteristics of coal reservoir pores and coal facies in Liulin district, Hedong coal field of China. Int. J. Coal Geol. 2010, 81, 117-127. [CrossRef]

19. Teng, J.; Yao, Y.B.; Liu, D.M.; Cai, Y.D. Evaluation of coal texture distributions in the southern Qinshui basin, North China: Investigation by a multiple geophysical logging method. Int. J. Coal Geol. 2015, 140, 9-22. [CrossRef]

20. Xu, H.; Tang, D.Z.; Mathews, J.P.; Zhao, J.L.; Li, B.Y.; Tao, S.; Li, S. Evaluation of coal macrolithotypes distribution by geo-physical logging data in the Hancheng Block, Eastern Margin, Ordos Basin, China. Int. J. Coal Geol. 2016, 165, 265-277. [CrossRef]

21. Ren, P.F.; Xu, H.; Tang, D.Z.; Li, Y.K.; Sun, C.H.; Tao, S.; Li, S.; Xin, F.D.; Cao, L.K. The identification of coal texture in dif-ferent rank coal reservoirs by using geophysical logging data in northwest Guizhou, China: Investigation by principal com-ponent analysis. Fuel 2018, 230, 258-265. [CrossRef]

22. Roslin, A.; Esterle, J.S. Electrofacies analysis using high-resolution wireline geophysical data as a proxy for inertinite-rich coal distribution in Late Permian Coal Seams, Bowen Basin. Int. J. Coal Geol. 2015, 152, 10-18. [CrossRef]

23. Charbucinski, J.; Nichols, W. Application of spectrometric nuclear borehole logging for reserves estimation and mine planning at Callide coalfields open-cut mine. Appl. Energy 2003, 74, 313-322. [CrossRef]

24. Fu, X.H.; Qin, Y.; Wang, G.G.X.; Rudolph, V. Evaluation of gas content of coalbed methane reservoirs with the aid of geophysical logging technology. Fuel 2009, 88, 2269-2277. [CrossRef]

25. Hou, H.H.; Shao, L.Y.; Guo, S.Q.; Li, Z.; Zhang, Z.J.; Yao, M.L. Evaluation and genetic analysis of coal structures in deep Jiaozuo Coalfield, northern China: Investigation by geophysical logging data. Fuel 2017, 209, 552-566. [CrossRef]

26. Zhou, F.D.; Yao, G.Q. Sensitivity analysis in permeability estimation using logging and injection-falloff test data for an anthracite coalbed methane reservoir in Southeast Qinshui Basin, China. Int. J. Coal Geol. 2014, 131, 41-51. [CrossRef]

27. Oyler, D.C.; Mark, C.; Molinda, G.M. In situ estimation of rock strength using logging. Int. J. Coal Geol. 2010, 83, 484-490. [CrossRef]

28. Shao, X.J.; Sun, Y.B.; Sun, J.M.; Tang, D.Z.; Xu, H.; Dong, X.X.; Lv, Y.M. Logging interpretation of coal petrologic parameters: A case study of Hancheng mining area. Pet. Explor. Dev. 2013, 40, 559-565. [CrossRef]

29. Li, J.Q.; Liu, D.M.; Yao, Y.B.; Cai, Y.D.; Qiu, Y.K. Evaluation of the reservoir permeability of anthracite coals by geophysical logging data. Int. J. Coal Geol. 2011, 87, 121-127. [CrossRef]

30. Karacan, C.O. Elastic and shear moduli of coal measure rocks derived from basic well logs using fractal statistics and radial basis functions. Int. J. Rock Mech. Min. Sci. 2009, 46, 1281-1295. [CrossRef]

31. Zhao, J.L.; Tang, D.Z.; Qin, Y.; Xu, H. Experimental study on structural models of coal macrolithotypes and its well logging responses in the Hancheng area, Ordos Basin, China. J. Petrol. Sci. Eng. 2018, 166, 658-672. [CrossRef]

32. Yu, H.Y.; Khan, F.; Garaniya, V. An alternative formulation of PCA for process monitoring using distance correlation. Ind. Eng. Chem. Res. 2016, 55, 656-669. [CrossRef]

33. Granato, D.; Santos, J.S.; Escher, G.B.; Ferreira, B.L.; Maggio, R.M. Use of principal component analysis (PCA) and hierarchical cluster analysis (HCA) for multivariate association between bioactive compounds and functional properties in foods: A critical perspective. J. Food Sci. 2018, 72, 83-90. [CrossRef]

34. Li, W.; Peng, M.J.; Wang, Q.Z. Improved PCA method for sensor fault detection and isolation in a nuclear power plant. Nucl. Eng. Technol. 2019, 51, 146-154. [CrossRef]

35. Asante-Okyere, S.; Shen, C.B.; Ziggah, Y.Y.; Rulegeya, M.M. Principal component analysis (PCA) based hybrid models for the accurate estimation of reservoir water saturation. Comput. Geosci. 2020, 145, 104555. [CrossRef]

36. Cai, Y.D.; Liu, D.M.; Li, J.Q.; Qiu, Y.K. Geological controls on prediction of coalbed methane of No. 3 coal seam in Southern Qinshui Basin, North China. Int. J. Coal Geol. 2011, 88, 101-112. [CrossRef]

37. Wang, H.; Yao, Y.B.; Liu, D.M.; Pan, Z.J.; Yang, Y.H.; Cai, Y.D. Fault-sealing capability and its impact on coalbed methane distribution in the Zhengzhuang field, southern Qinshui Basin, North China. Nat. Gas. Sci. Eng. 2016, 28, 613-625. [CrossRef]

38. Liu, S.Q.; Sang, S.X.; Liu, H.H.; Zhu, Q.P. Growth characteristics and genetic types of pores and fractures in a high-rank coal reservoir of the southern Qinshui basin. J. Cent. South Univ. 2015, 64, 140-151. [CrossRef]

39. Zhang, J.Y.; Liu, D.M.; Cai, Y.D.; Pan, Z.J.; Yao, Y.B.; Wang, Y.J. Geological and hydrological controls on the accumulation of coalbed methane within the No. 3 coal seam of the southern Qinshui Basin. Int. J. Coal Geol. 2017, 182, 94-111. [CrossRef]

40. Zhang, P.; Meng, Z.P.; Jiang, S.; Chen, X.M. Characteristics of in-situ stress distribution in Zhengzhuang Region, Southern Qinshui Basin, China and its stress path during depletion. Eng. Geol. 2020, 264, 105413. [CrossRef]

41. Wei, C.T.; Qin, Y.; Wang, G.G.X.; Fu, X.H.; Jiang, B.; Zhang, Z.Q. Simulation study on evolution of coalbed methane reservoir in Qinshui basin, China. Int. J. Coal Geol. 2007, 72, 53-69. [CrossRef] 
42. Lv, Y.M.; Tang, D.Z.; Xu, H.; Luo, H.H. Production characteristics and the key factors in high-rank coalbed methane fields: A case study on the Fanzhuang Block, Southern Qinshui Basin, China. Int. J. Coal Geol. 2012, 96, 93-108. [CrossRef]

43. Standardization Administration of China; General Administration of Quality Supervision, Inspection and Quarantine of China. Chinese National Standard GB/T 18023-2000. Classification of for Bituminous Coal; Standards Press of China: Beijing, China, 2008. (In Chinese)

44. Standardization Administration of China; General Administration of Quality Supervision, Inspection and Quarantine of China. Chinese National Standard GB/T 212-2008. Proximate Analysis of Coal; Standards Press of China, Beijing, China, 2008. (In Chinese)

45. Shi, J.X.; Zeng, L.B.; Dong, S.Q.; Wang, J.P.; Zhang, Y.Z. Identification of coal structures using geophysical logging data in Qinshui Basin, China: Investigation by kernel Fisher discriminant analysis. Int. J. Coal Geol. 2020, 217, 103314. [CrossRef]

46. Zhao, Z.Q.; Tao, S.; Tang, D.Z.; Chen, S.D.; Ren, P.F. A mathematical method to identify and forecast coal texture of multiple and thin coal seams by using logging data in the Panguan syncline, western Guizhou, China. Nat. Gas Sci. Eng. 2020, $185,106616$. [CrossRef]

47. Guo, Y.B.; Chen, H.X. Fault diagnosis of VRF air-conditioning system based on improved Gaussian mixture model with PCA approach. Int. J. Refrig. 2020, 118, 1-11. [CrossRef]

48. Wang, Y.J.; Liu, D.M.; Cai, Y.D.; Yao, Y.B.; Pan, Z.J. Constraining coalbed methane reservoir petrophysical and mechanical properties through a new coal structure index in the southern Qinshui Basin, northern China: Implications for hydraulic fracturing. AAPG Bull. 2020, 104, 1817-1842. [CrossRef] 